\title{
Investigation on solar humidification dehumidification water desalination system using a closed-air cycle
}

\author{
Ahmed Mohamed ${ }^{1}$, Mahmoud ahmed $^{2}$, and abanob Shahdy ${ }^{2}$ \\ ${ }^{1}$ Sohag University Faculty of Technology and Education \\ ${ }^{2}$ Affiliation not available
}

September 16, 2020

\begin{abstract}
This research presents a theoretical and experimental study of a solar humidification dehumidification water desalination system based on a closed-air cycle. The results show that productivity enhances with increasing air flow-rate while the gain output ratio decreases. The gain output ratio and productivity improve with raising the temperature of water. The average value of gain output ratio is $0.71,0.74,0.78$, and 0.81 , and productivity is $1.46 \mathrm{~kg} / \mathrm{h}, 2.59 \mathrm{~kg} / \mathrm{h}, 4.40 \mathrm{~kg} / \mathrm{h}$, and $6.99 \mathrm{~kg} / \mathrm{h}$ at water temperatures of $40{ }^{\circ} \mathrm{C}, 50{ }^{\circ} \mathrm{C}, 60{ }^{\circ} \mathrm{C}$, and $70{ }^{\circ} \mathrm{C}$, respectively. The maximum gain output ratio of 0.86 is recorded at water to air mass flow-rate ratio of 5 . Increasing the cooling water flow-rate has a positive effect on both productivity and gain output ratio. Moreover, The results indicate that the fresh water cost is $0.012 \$ / \mathrm{L}$. Finally, a good agreement is noted between the theoretical and experimental results.
\end{abstract}

\section{Hosted file}

Manuscript.pdf available at https://authorea.com/users/359152/articles/481357-investigationon-solar-humidification-dehumidification-water-desalination-system-using-a-closed-aircycle 